\title{
Gangguan Psikologis pada Pasien Diabetes Melitus Di Masa Pandemi Covid-19 Dusun Kanoman, Pleret, Bantul
}

\author{
Rizqi Wahyu Hidayati ${ }^{1}$, Latifah Susilowati ${ }^{2}$, Novita Nirmalasari ${ }^{3}$ \\ ${ }^{1,2,3}$ Keperawatan (S1), Fakultas Kesehatan, Universitas Jenderal Achmad Yani, Yogyakarta, \\ Indonesia \\ e-mail: 1rizqiwahyu2989@gmail.com, ${ }^{2}$ latsa7ers@yahoo.com, ${ }^{3}$ novitanirmalasari@gmail.com
}

\begin{abstract}
ABSTRAK Pandemi Covid-19 menyebabkan berbagai masalah psikologis, terutama pada pasien dengan penyakit komorbid, salah satunya yaitu diabetes melitus. Hal ini terbukti bahwa sebanyak $65 \%$ orang mengalamai masalah tersebut, antara lain depresi, cemas, gangguan tidur, hingga sindrom pasca trauma. Namun, hingga saat ini, gangguan psikologis tersebut masih dianggap sebelah mata. Hal ini juga terjadi di Dusun Kanoman, Pleret, Bantul. Sehingga pengabdian ini bertujuan untuk memeriksa status psikologis masyarakat yang menderita Diabetes Melitus di masa pandemic Covid. Kegiatan pengabdian meliputi pemeriksaan psikologis dengan menggunakan kuesioner Depression, Anxiety, and Stress 21 Scale (DASS 21) dan konsultasi. Kuesioner ini memeriksa depresi, cemas, dan stress yang dialami penderita diabetes melitus. Kemudian, hasil dianalisis menggunakan SPSS 25. Berdasarkan hasil diketahui bahwa $20 \%$ penderita mengalami depresi sedang, $13,3 \%$ mengalami cemas sedang, dan $6,7 \%$ mengalami stress ringan. Setelah pemeriksaan, peserta diarahkan ke meja konsultasi. Di meja tersebut, peserta diajarkan cara-cara untuk manajemen relaksasi seperti nafas dalam dengan disertai afirmasi positif, spiritual relaxation techniques, dan terapi musik.
\end{abstract}

\section{KATA KUNCI: Gangguan Psikologis; Covid-19; Diabetes Melitus}

ABSTRACT The Covid-19 pandemic caused various psychological problems, especially in patients with comorbid diseases, such as diabetes mellitus. It was proven that as much as 65\% of people who experience these problems, including depression, anxiety, sleep disorders, and post-traumatic syndrome. However, until now, this psychological disorder is not still considered. This also happened in Kanoman, Pleret, Bantul. So that this service aimed to examine the psychological status of people suffering from Diabetes Mellitus during the Covid pandemic. Service activities include psychological examinations using the Depression, Anxiety, and Stress 21 Scale (DASS 21) questionnaire and consultation. This questionnaire examines depression, anxiety, and stress experienced by people with diabetes mellitus. Then, the results were analysed using SPSS 25. Based on the results, it was found that $20 \%$ of patients had got moderate depression, $13.3 \%$ moderate anxiety, and $6.7 \%$ mild stress. After the examination, participants were directed to the consultation table. At the table, participants had mental health promotion about relaxation management techniques such as deep breathing accompanied by positive affirmations, spiritual relaxation techniques, and music therapy.

KEYWORDS: Psychologic Disorders; Covid-19; Diabetes Mellitus 


\section{Pendahuluan}

Pandemi Covid sudah dari akhir tahun 2019 hingga saat ini. Berbagai upaya pemerintah telah dilakukan untuk menanggulangi bencana tersebut, terutama mengurangi jumlah kematian, salah satunya melalui PPKM akibat BOR RS di Yogyakarta lebih dari 90\%[1]. Hal ini dapat meningkatkan gangguan psikologis pada masyarakat, terutama penderita penyakit kronik, contohnya diabetes melitus. Hal ini dikarenakan diabetes melitus merupakan salah satu penyakit komorbid dari Covid-19 yang dapat meningkatkan risiko kematian. Saat ini Indonesia merupakan negara tertinggi kedua di dunia dan Yogyakarta peringkat ketiga nasional untuk penderita diabetes melitus[2]. Kondisi yang terjadi saat ini meningkatkan stress[3]. Hal ini dikarenakan Covid merupakan salah satu bentuk stressor psikososial. Berdasarkan data Persatuan Dokter Spesialis Jiwa Indonesia (PDSKJI), sebanyak 4010 orang melakukan swaperiksa kejiwaan pada masa pandemic Covid-19 didapatkan hasil bahwa 64,8\% mengalami masalah psikologis[4]. Hal ini sesuai dengan Liu di dalam Windarwati et al., gejala psikologis yang terjadi selama masa pandemic adalah depresi, cemas, insomnia, gejala stress, dan Post Traumatic Synrome Disorder (PTSD)[5]. Hal ini juga terjadi di Dusun Kanoman, peserta kegiatan merasa takut untuk kontrol di pelayanan kesehatan. Hal ini berakibat pada pola hidup yang tidak terkontrol. Ditambah lagi, mereka merasa takut jika ada warga yang terkonfirmasi postif. Sehingga perlu diketahui kondisi psikologis pada penderita diabetes melitus di kala pandemic Covid-19 agar bisa meningkatkan kesejahteraan psikologis dan meminimalkan risiko komplikasi penyakit.

\section{Metode}

Kegiatan pengabdian ini dilaksanakan di Dusun Kanoman, Pleret, Bantul. Pertama, Tim dari Universitas Jenderal Achmad Yani Yogyakarta berkoordinasi dengan dukuh Dusun Kanoman. Hal ini perlu dilakukan untuk pendataan jumlah penderita diabetes melitus yang ada pada dusun tersebut. Selain itu, kegiatan ini dilakukan secara tatap muka di masa pandemi Covid-19, sehingga perlu koordinasi dalam penanggulan penyebaran Covid-19 saat kegiatan berlangsung. Salah satu upaya yang dilakukan dalam mengantisipasi penyebaran yaitu tempat duduk peserta diberikan jarak, disediakan cuci tangan, dan diminta menggunakan masker sepanjang acara berlangsung.

Panitia menyiapkan 3 buah meja yang terdiri dari meja pendaftaran dan pengisian DASS 21, pemeriksaan fisik, dan konsultasi. Peserta dianjurkan mengisi kuesioner sebanyak 21 item dari kuesioner DASS 21 dan melengkapi lembar identitas seperti nama, usia, dan jenis kelamin. Kemudian, peserta beralih ke meja 2 yaitu pemeriksaan tekanan darah dan gula darah sewaktu. Hal ini digunakan sebagai data awal kadar glukosa darah sewaktu peserta. Terakhir, mereka akan berada di meja konsultasi hasil pemeriksaan.

\section{Hasil dan Pembahasan}

Tabel 1. Data Demografi

\begin{tabular}{clcc}
\hline No & \multicolumn{1}{c}{ Kategori } & Mean $($ SD) & \% $(\mathbf{N}=\mathbf{1 4})$ \\
\hline \multirow{3}{*}{1} & Jenis Kelamin & & \\
\cline { 2 - 4 } & Laki-laki & & 26,7 \\
\cline { 2 - 4 } & Perempuan & & 73,3 \\
\hline \multirow{2}{*}{2} & Usia & 54,47 & \\
& & $(8,17)$ & \\
\hline
\end{tabular}

Berdasarkan tabel diketahui bahwa mayoritas peserta adalah perempuan dengan prosentase $73,3 \%$. Hal ini sesuai dengan penelitian bahwa perempuan memiliki 
prosentase lebih tinggi menderita diabetes melitus adalah perempuan[6][7]. Hal ini berhubungan dengan paritas dan kehamilan yang merupakan faktor risiko terjadi penyakit diabetes melitus[8]. Rata-rata yang menderita diabetes yaitu 54 tahun. Berdasarkan Depkes (2009) usia ini termasuk dalam kategori lansia awal dengan rentang 46-55 tahun[9]. Hasil ini didukung oleh penelitian Kurniawaty \& Yanita bahwa usia merupakan salah satu faktor kejadian diabetes melitus tipe 2[10]. Pendapat yang sama juga dikemukakan oleh Hidayati dan Rukmi penderita diabetes paling banyak berusia di bawah 59 tahun[6]. Hal ini dikarenakan penuaan dapat menyebabkan sensitivitas insulin dan fungsi metabolisme glukosa menurun[10].

Tabel 2. Pemeriksaan Psikologis dan Fisik

\begin{tabular}{lcc}
\hline \multicolumn{1}{c}{ Kategori } & Mean (SD) & $\begin{array}{c}\text { Prosentase } \\
(\mathrm{N}=15)\end{array}$ \\
\hline Sistol & $132,68(21,87)$ & \\
\hline Diastol & $83,33(11,13)$ & \\
\hline GDS & & 86,67 \\
1. <= 200 MgdL & 13,3 \\
2. > 200 MgdL & \\
\hline Depresi & 73,3 \\
1. Normal & 6,7 \\
2. Ringan & 20,0 \\
3. Sedang & 0 \\
4. Berat & 0 \\
5. Sangat Berat & \\
\hline Cemas & 46,7 \\
1. Normal & 26,7 \\
2. Ringan & 13,3 \\
3. Sedang & 6,7 \\
4. Berat & 6,7 \\
5. Sangat Berat & \\
\hline Stres & 93,3 \\
1. Normal & 6,7 \\
2. Ringan & 0 \\
3. Sedang & 0 \\
4. Berat & 0 \\
5. Sangat Berat &
\end{tabular}

Berdasarkan hasil diketahui bahwa rata-rata sistol dan diastol peserta yaitu 132, 68 dan 83,33. Berdasarkan JNC VIII, tekanan darah tersebut masuk ke dalam kategori pre hipertensi[11]. Penelitian lain menyebutan bahwa rata-rata penderita hipertensi memiliki tekanan darah pada pra hipertensi dan hipertensi derajat 1[6]. Penelitian lain menyebutkan pada pasien diabetes terdapat $41 \%$ menderita hipertensi dan 56\% normal. Selain itu, pada pengkajian peserta pengabdian masyarakat didapatkan hasil kadar glukosa darah sewaktu mayoritas kurang dari sama dengan $200 \mathrm{mgdl}$. Hal ini sesuai dengan penelitian lain bahwa gula darah sewaktu pasien diabetes pada kategori normal. Hal ini bisa terjadi karena manajemen diabevtes yang dilakukan oleh masyarak di Dusun Kanoman. Beberapa dari mereka mengatakan bahwa setelah mengetahui diabetes, ada yang melakukan pembatasan pada makanan manis atau meningkatkan kegiatan olah raga, seperti jalan kaki hanya 30 menit setiap hari. Aktivitas fisik selama 30 menit perhari atau 150 menit/ minggu dengan intensitas sedang. Hal ini dilakukan hingga gula darah 
dan tekanan darah terkontrol hingga baik[2]. Diabetes dan hipertensi memiliki hubungan dengan keeratan hubungan yaitu rendah ${ }^{(11)}$. Penderita diabetes cenderung memiliki komplikasi hipertensi kemudian bisa menjadi faktor risiko terhadap penyakit kardiovaskuler [12][13].

- Berdasarkan tabel diketahui bahwa persentase yang memiliki depresi ringan dan sedang yaitu $6,7 \%$ dan $20 \%$. Hal ini sesuai dengan penelitian Kholid bahwa penderita diabetes dapat mengalami depresi ringan dan sedang[14]. Depresi dapat mempengaruhi satu sama lain dengan penyakit diabetes. Hal ini dikarenakan orang dengan diabetes melitus dapat menderita depresi karena prognosis penyakitnya, tetapi depresi tersebut juga dapat meningkatkan komplikasi hingga kematian pada penderita diabetes melitus. Proses diabetes menjadi depresi diakibatkan karena stressor psikososial kronik yang dialaminya. Kemudian, depresi memperburuk kondisi diabetesnya lebih dikarenakan adanya peningkatan sekresi dan hormone kontraregulasi, perubahan fungsi transport glikosa, dan peningkatan aktivasi inflamasi[3].

Gangguan psikologis lain yaitu cemas, pada kegiatan ini sebanyak 6,7\% peserta mengalami cemas berat dan sangat berat. Hal ini juga terjadi pada penelitian lain bahwa pasien diabetes melitus dapat mengalami kecemasan berat hingga sangat berat[14]. Kecemasan dan depresi pada pasien diabetes terjadi karena stressor psikososial akibat penyakit kronik yang diderita[3]. Kecemasan yang dialami pasien diabetes akan meningkatkan risiko hiperglikemia[15]. Hal yang sama juga terjadi pada stress. Pada kegiatan ini sebanyak 6,7\% peserta mengalami stress ringan. Stres yang dialami juga merupakan dampak dari stress psikososial seperti cemas dan depresi[3].

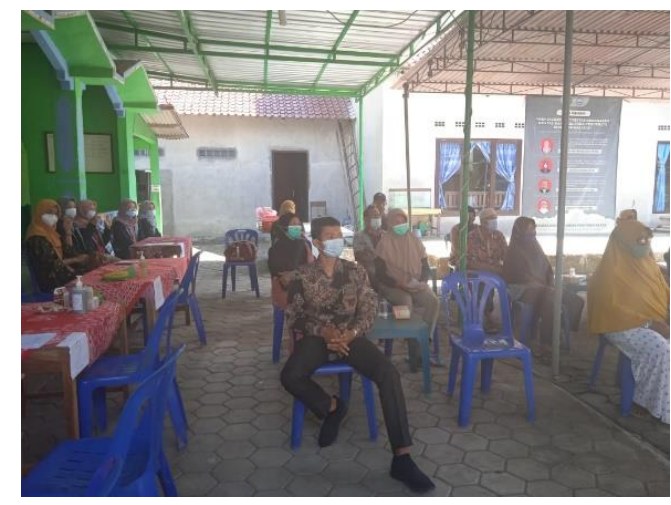

A. Penjelasan Kegiatan

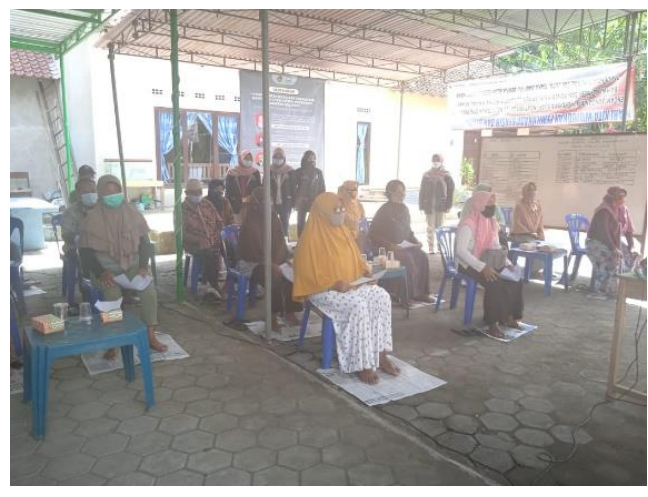

B. Evaluasi Kegiatan

\section{Kesimpulan}

Berdasarkan pencapaian kegiatan, kegiatan ini sudah terlaksana dengan baik. Namun, perlu adanya koordinasi lebih lanjut mengingat hasil skrining menggunakan kuesioner DASS 21 beberapa peserta mengalami depresi berat, cemas berat hingga sangat berat, dan stress ringan. Pada saat kegiatan juga dilakukan konsultasi, tetapi konsultasi dirasa belum cukup untuk mengatasi depresi dan kecemasan berat. Sehingga tata laksana kolaborasi dengan pelayanan kesehatan diperlukan.

\section{Ucapan terima kasih}

Kami mengucapkan terima kasih kepada kader Dukuh Dusun Kanoman, Pleret, Bantul yang telah membantu pelaksanaan pengabdian. Selain itu, kami juga mengucapkan terima kasih kepada Himpunan Mahasiswa Keperawatan yang sudah menjadi fasilitator dalam kegiatan. Terakhir terima kasih kami ucapkan kepada Fakultas Kesehatan Universitas Jenderal Achmad Yani Yogyakarta yang telah memberikan ijin pelaksaan pengabdian tersebut. 


\section{Daftar Pustaka}

[1] Satgas Covid, “Analisis Data Covid-19," Satgas Covid 19, 2020. .

[2] Infodatin Kemenkes RI, "Tetap Produktif, Cegah, dan Atasi Diabetes Melitus." 2020.

[3] R. A. Harista and R. Lisiswanti, "Depresi pada Penderita Diabetes Mellitus Tipe 2 Depression in Patients with Type 2 Diabetes Mellitus," vol. 4, pp. 7377, 2015.

[4] PDSKJI, "5 Bulan Pandemi Covid di Indonesia," 2020. .

[5] H. Dwi, W. Oktaviana, I. Mukarromah, N. Asih, and L. Ati, "In the middle of the COVID-19 outbreak: Early practical guidelines for psychosocial aspects of COVID-19 in East Java , Indonesia," Psychiatry Res., vol. 293, no. April, p. 113395, 2020, doi: 10.1016/j.psychres.2020.113395.

[6] R. W. Hidayati and D. K. Rukmi, "The Benar Relaxation Therapy (Brt) Decreasing Psychologic Symptoms In Diabetes Type Ii In Candibinangun Distric," J. Keperawatan Respati Yogyakarta; Vol 8 No 2 MAY $2021 D O$ 10.35842/jkry.v8i2.606, Jun. 2021.

[7] Mildawati, N. Diani, and A. Wahid, "Hubungan Usia, Jenis Kelamin dan Lama Menderita Diabetes dengan Kejadian Neuropati Perifer Diabateik," Caring Nurs. J., vol. 3, no. 2, pp. 31-37, 2019.

[8] Internasional Association for the Study of Pain, "Epidemiology of neuropathic pain : how common is neuropathic pain, and what is its impact? neuropathic pain," 2015. .

[9] I. G. P. N. A. Santika, "Hubungan Indeks Massa Tubuh (Imt) Dan Umur Terhadap Daya Tahan Umum (Kardiovaskuler) Mahasiswa Putra Semester Ii Kelas A Fakultas Pendidikan Olahraga Dan Kesehatan Ikip Pgri Bali Tahun 2014," J. Pendidik. Kesehat. Rekreasi, vol. 1, pp. 42-47, 2015.

[10] B. Kurniawaty, Evi; Yanita, "Faktor-Faktor yang Berhubungan dengan Kejadian Diabetes Melitus Tipe II," Majority, vol. 5, no. 2, pp. 27-31, 2016.

[11] Majid, No TitleAsuhan Keperawatan Pada Pasien Dengan Gangguan Sistem. Kardiovaskular. Pustaka Baru Press, 2017.

[12] A. E. Winta, E. Setiyorini, and N. A. Wulandari, "Hubungan Kadar Gula Darah Dengan Tekanan Darah Pada Lansia Penderita Diabetes Tipe 2 ( The Correlation Of Blood Glucose Level and Blood Pressure of Elderly With Type 2 Diabetes )," vol. 5, no. 2, pp. 163-171, 2018, doi: 10.26699/jnk.v5i2.ART.p163.

[13] D. R. Fitri, "Diagnose Enforcement And Treatment Of," vol. 4, pp. 47-51, 2007.

[14] A. Z. Kholid, "Hubungan Depresi, Anxiety Dan Stres Dengan Kadar Gula Darah Pada Pasien Dm Tipe Ii Di Persadia Rs Pku Muhammadiyah YogyakartA," 2019.

[15] E. U. Dewi, "Hubungan Tingkat Kecemasan Terhadap Terkendalinya Gula Darah Pada Pasien Diabetes Melitus Di Puskesmas Pakis Surabaya,” 2011. 